\title{
Seasonal and spatial variability of planktonic heliozoa in Lake Constance
}

\author{
Uwe Zimmermann*, Helga Müller**, Thomas Weisse ${ }^{* * *}$ \\ Limnological Institute, University of Konstanz, PO Box 5560, D-78434 Konstanz, Germany
}

\begin{abstract}
Planktonic heliozoa were investigated at a mid-lake and an inshore station in Lake Constance (Germany) from April to November 1993. Integrated water samples were taken over 0 to $8 \mathrm{~m}$ and 8 to $20 \mathrm{~m}$ depth intervals at the deep mid-lake station and over 0 to $2 \mathrm{~m}$ depth at the shallow inshore station. Heliozoans were counted and identified to genus level in live samples. The following genera were identified: Actinophrys, Raphidocystis, Heterophrys, Chlamydaster, Choanocystis, Raphidiophrys, and Pterocystis. Small heliozoans (10 to $20 \mu \mathrm{m}$, mainly Heterophrys and Choanocystis) generally dominated the community in terms of abundance. Large genera (Actinophrys, Raphidocystis) were, however, the major contributors to total biovolume. Total cell concentrations remained below detection limits from April to mid-June. Maxima of up to 6.6 ind. $\mathrm{ml}^{-1}$ were observed in summer; smaller peaks occurred in autumn. Heliozoan cell numbers were significantly positively correlated with chlorophyll a concentration close to the surface. Negative trends were found in relation to potential heliozoan competitors or predators such as rotifers and crustacea. Community biovolumes of up to $60 \mathrm{~mm}^{3} \mathrm{~m}^{-3}$ were recorded in mid-summer The seasonal succession of the dominant genera was similar at both stations. The vertical distribution of heliozoans, examined on 2 occasions in summer and autumn, was positively correlated with chlorophyll $a$ and temperature. We further studied the horizontal distribution of heliozoans at 8 stations across the northwestern part of Lake Constance on one occasion in late summer. Cell numbers recorded varied by a factor of 2 . In situ growth rates of heliozoans were measured in diffusion chambers after the exclusion of larger potential predators at the mid-lake station on 2 occasions. Growth rates of distinct genera ranged from 0.06 to $0.59 \mathrm{~d}^{-1}$, community growth rates from 0.3 to $0.5 \mathrm{~d}^{-1}$ Based on growth rates and biomasses, we calculated the potential heliozoan production. Results suggest that during periods of their maximum abundance heliozoan community production is similar to average production estimates of ciliates and heterotrophic nanoflagellates. The seasonal mean heliozoan production is, however, equivalent to only about $1 \%$ of the combined ciliate and flagellate production.
\end{abstract}

KEY WORDS: Heliozoa Planktonic protozoa S Seasonal dynamics - Lake Constance

\section{INTRODUCTION}

Heliozoans have been known for more than 2 centuries; yet they have rarely been included in limnological studies. The first detailed account on the ecology of these sarcodines was given by Penard (1904). More

- Present address: Labor für hydraulisches Versuchswesen, Gewässerschutz und Ökologie (Hydrolabor Schleusingen), PO Box 66, D-98549 Schleusingen, Germany

- Addressee for correspondence.

E-mail: helga.mueller@uni-konstanz.de

-.Present address: Max Planck Institute for Limnology, PO Box 165, D-24302 Plön, Germany recently, Rainer (1968) described the preference and tolerance of 22 species in relation to environmental factors such as $\mathrm{pH}$ and temperature. Takahashi \& Yi Ling (1980) examined the vertical distribution of Sticholonche zanclea in the Pacific Ocean. Bérzinš \& Stensdotter (1990) investigated the adequacy of different substrate types for rhizopods and some heliozoans. Until recently, the prevailing opinion was that heliozoans prefer solid substrate surfaces like sediment and macrophytes (cf. Rainer 1968) or live attached to detrital particles (Laybourn-Parry et al. 1991). Research conducted over the last 2 decades has revealed, however, that heliozoans are also common in freshwater plankton, at times even in high numbers comparable to 
those of other pelagic protozoa (reviewed by Arndt 1993)

In the large, prealpine Lake Constance, the microbial food web has been examined for more than $10 \mathrm{yr}$. Among protozoa, these studies have concentrated on the ecology of heterotrophic nanoflagellates (Güde 1986, Weisse 1990, 1991, Jürgens \& Güde 1991) and ciliates (Müller 1989, Müller et al. 1991, Müller \& Weisse 1994). In this paper, we extend the existing knowledge on the significance of pelagic protozoa by presenting the first quantitative data on heliozoa in Lake Constance.

\section{MATERIALS AND METHODS}

Lake Constance ('Bodensee') is a warm-monomictic prealpine lake with a surface area of $540 \mathrm{~km}^{2}$ and a maximum depth of $252 \mathrm{~m}$ (Geller \& Güde 1989). The lake is thermally stratified from April through October. Its current trophic state is considered mesotrophic (Tilzer et al. 1991). Our study was conducted in Überlinger See, a fjord-like basin with an area of $65 \mathrm{~km}^{2}$ and maximum depth of $147 \mathrm{~m}$, in the northwestern part of the lake (Fig. 1).

Water samples were taken with a $2 \mathrm{~m}$ long water bottle at weekly intervals from April to November 1993. Samples were integrated for 0 to $2 \mathrm{~m}$ depth at a littoral station (M2, $z=2.2 \mathrm{~m}$ ) and for 0 to $8 \mathrm{~m}$ and 8 to $20 \mathrm{~m}$ depth, respectively, at a mid-lake station $(\mathrm{M} 1, \mathrm{z}=$ $147 \mathrm{~m}$ ). The latter station has been used as the routine sampling station by the Limnological Institute Constance since 1979 (e.g. Müller 1989, Tilzer et al. 1991, Weisse 1991, Sommer et al. 1993). Live samples of 1 to 3 l volume were concentrated by gravity filtration using a $10 \mu \mathrm{m}$ plankton net. Aliquots corresponding to between 100 and $300 \mathrm{ml}$ of the original sample were examined in a settling chamber $(2 \mathrm{ml}$ vol $\}$ by inverted microscopy using phase contrast. We checked the precision and accuracy of this methud by splitting 1 sample into 3 subsamples and counting each subsample 3 times. The coefficient of variability (CV) of total cell numbers calculated according to Lozán (1992) was $7 \%$ at abundances ranging from 500 to 1000 heliozoans $\mathrm{l}^{-1}$. The CV of the abundance of individual genera varied from $8.5 \%$ in the most numerous up to $86.5 \%$ in the rarest genus.

Identification to the genus level followed the keys by Rainer (1968) and Page \& Siemensma (1991). Live specimens were examined by phase contrast microscopy for different morphological criteria, especially size and shape of skeletal elements. Cell size was measured by a calibrated eyepiece micrometer. Biovolume was calculated assuming spherical cell bodies of the heliozoans.

Parallel counts of total heliozoans, without discrimination of genera, were performed in fixed samples for the entire series at the mid-lake station, depth interval 0 to $8 \mathrm{~m}$. An aliquot of $250 \mathrm{ml}$ was fixed with acid Lugol's iodine (final concentration $1 \%$ ), allowed to sediment for $24 \mathrm{~h}$ and then concentrated to $100 \mathrm{ml}$ by gently removing the supernatant. Half of the remaining $100 \mathrm{ml}$ was counted by inverted microscopy (Utermöhl 1958). Generally, heliozoan numbers obtained from live counts were slightly higher than those determined in fixed samples. One maximum of very small heliozoans, however, could be detected only by the live counting procedure. These results will be reported in full detail elsewhere (U. Zimmermann \& T. Weisse unpubl.).

The vertical and horizontal distribution of planktonic heliozoans were investigated in fixed samples. Because proper discrimination of genera was impossible

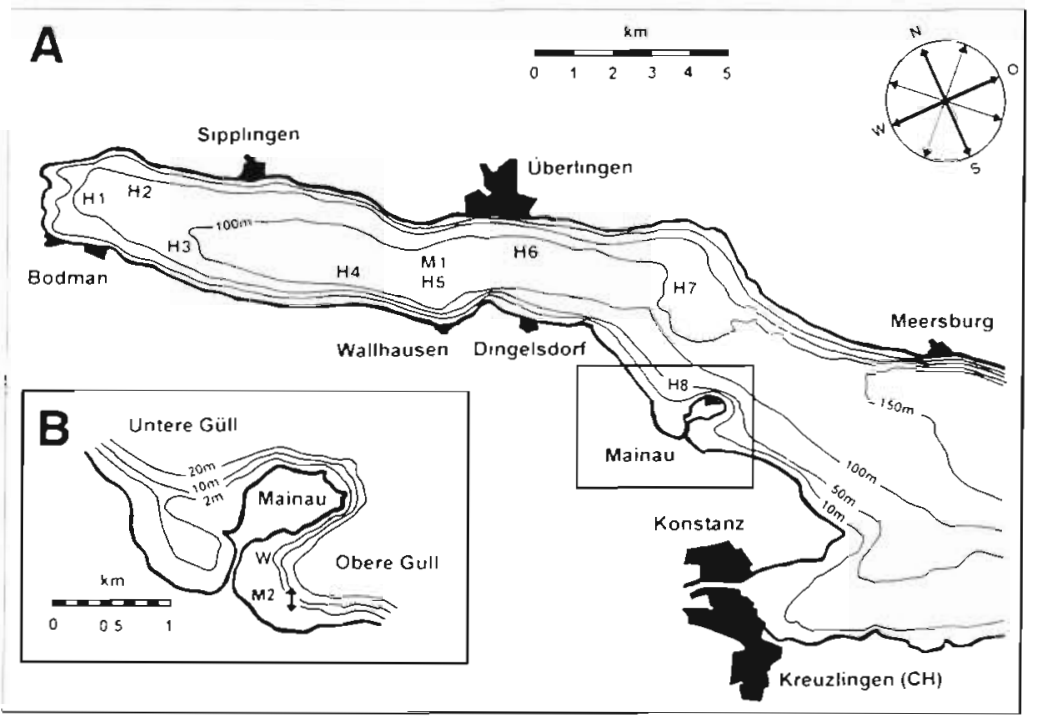

Fig. 1. Study area with sampling locations (A) Uberlinger See with routine mid-lake station (M1) and sampling stations of the case study on the horizontal distribution (H1 to H8). (B) Obere Güll with routine littoral station (M2) and location of in situ growth rate measurements (W) 
in fixed heliozoans we measured in those samples only total heliozoan number (vertical profiles) or abundance in 3 different size classes (<20 $\mu \mathrm{m}, 20-30 \mu \mathrm{m}$, and $>30 \mu \mathrm{m}$, horizontal distribution), respectively. Vertical profiles were recorded at the pelagic station on August 17 and October 12,1993 . Samples were taken from discrete depths $(0,2,4,6,8,10,15,20$, 25,30 , and $50 \mathrm{~m}$ ), and total numbers of heliozoans were counted by inverted microscopy. The horizontal distribution of heliozoans was examined in fixed samples taken from the upper $8 \mathrm{~m}$ of the water column at 8 stations across Überlinger See in early August (H1 to H8; Fig. 1). The coefficient of variability (CV) of total cell numbers in fixed samples, determined as given above for live samples, was $10 \%$.

In situ growth experiments were performed at Stn W near the littoral station in summer and autumn. Water samples from $3 \mathrm{~m}$ depth were prefiltered through a $140 \mu \mathrm{m}$ mesh screen to exclude larger predators and then poured into diffusion chambers of 3.51 volume (Müller \& Weisse 1994). These were exposed at $3 \mathrm{~m}$ depth for $2 \mathrm{~d}$. A $10 \mu \mathrm{m}$ mesh gauze was mounted at 2 sides of the chamber to allow for the exchange of water and smaller plankton (algae, heterotrophic nanoflagellates) during the incubation period. Samples of $500 \mathrm{ml}$ each were taken at the beginning and after 24 and $48 \mathrm{~h}$. Growth rates of heliozoa $\left(\mu, \mathrm{d}^{-1}\right)$ were calculated from changes in log-transformed cell numbers and least-squares linear regression analysis. Generation times $(G)$ were calculated as $G=\frac{\ln 2}{\mu}$. The resulting growth rates were combined with biomasses recorded at the mid-lake sampling location to estimate the potential production of pelagic heliozoans in Lake Constance.

We compared the seasonal and spatial distribution of heliozoan numbers to chlorophyll a concentration and to numbers of ciliates, rotifers and crustaceans. Those data were obtained with standard methods by various researchers of the Limnological Institute Constance in parallel to the present investigation.

\section{RESULTS}

\section{Seasonal dynamics of community composition, abundance, and biovolume}

We found 7 heliozoan genera in Lake Constance during the study period as listed in Table 1 together with cell dimensions. The following morphologic crite- ria were most important for taxonomic identification. Actinophrys: large cell size, central nucleus, absence of skeletal elements, large peripheral contractile vacuole. Raphidocystis: 2 different types of spicules (tubular and cup-shaped), and scales. Raphidiophrys: curved, spindle-shaped scales loosely attached to cell body and basal part of axopods. Heterophrys: thick gelatinous coat in which needle shaped spicules were embedded. Chlamydaster: gelatinous coat, no skeletal elements. Choanocystis: scales and short, slightly curved spicules. Pterocystis: very small cell size, scales and long tubular spicules.

The seasonal course of total heliozoan abundance was similar at both stations (Fig. 2). In April and May, total abundance of heliozoa was too low $\left(<3\right.$ ind $\left.\mathrm{I}^{-1}\right)$ to be detected by our sampling technique. Heliozoans were first recorded in mid-June at the end of the 'clearwater' phase, a regular phenomenon occurring in Lake Constance at the end of spring which is caused by grazing zooplankton (mainly Daphnia) (Lampert 1978). Within 2 or 3 wk cell numbers increased rapidly up to a first maximum of 5.7 heliozoans $\mathrm{ml}^{-1}$ at the mid-lake station (M1) and 5.5 heliozoans $\mathrm{ml}^{-1}$ at the littoral sta-
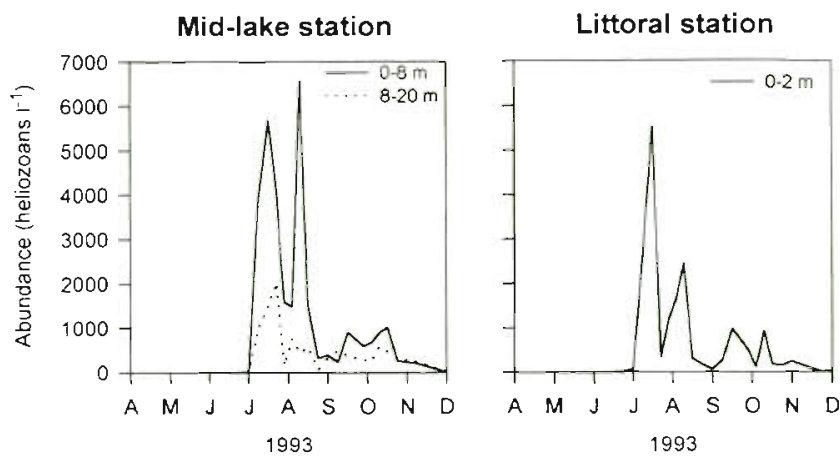

Fig. 2. Seasonal course of heliozoan abundance. Left: Midlake station (M1) 0 to $8 \mathrm{~m}$ (solid line) and 8 to $20 \mathrm{~m}$ (dotted line). Right: Littoral station (M2) 0 to $2 \mathrm{~m}$ 


\section{$0-8 \mathrm{~m}$}

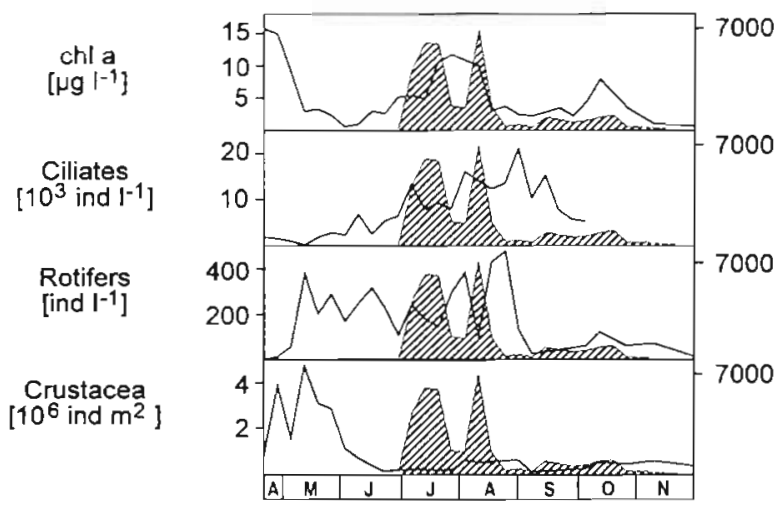

8-20 m

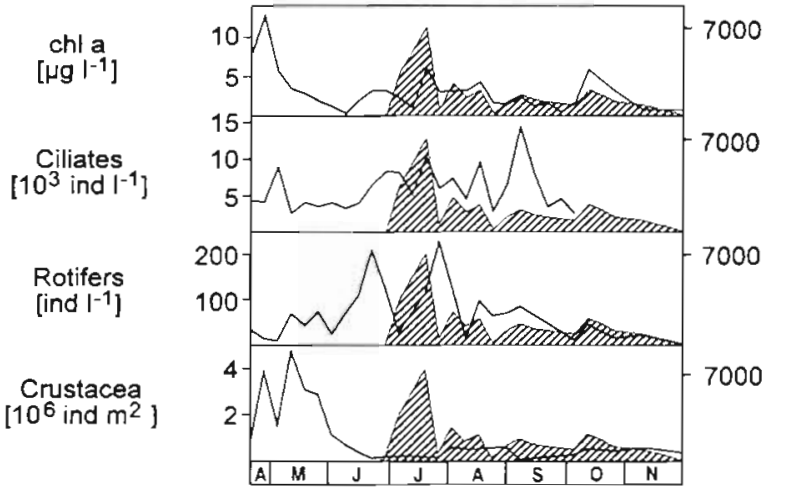

Fig. 3. Seasonal course of total heliozoan numbers (shaded area) at the mid-lake station in 0 to $8 \mathrm{~m}$ (upper) and 8 to $20 \mathrm{~m}$ (lower) in relation to chlorophyll a concentration and major zooplankton taxa which could have been prey, competitors or predators (Fig. 3). Positive trends were apparent to chlorophyll a in both depth layers, negative trends to rotifers and crustacea. Least-squares regression analysis revealed that, close to the surface ( 0 to $8 \mathrm{~m}$ ), heliozoan cell numbers were significantly correlated to chlorophyll a $\left(\mathrm{r}^{2}=\right.$ $0.35, p<0.01, n=19)$. In the deeper layer $(8$ to $20 \mathrm{~m}$ ) this relationship was only weak $\left(\mathrm{r}^{2}=0.18, \mathrm{p}<0.1, \mathrm{n}=\right.$ 17). Relationships to ciliates, rotifers and crustacea were insignificant at the $5 \%$ level $(\mathrm{p}<0.1$ in each case). Nevertheless, it is obvious from Fig. 3 that heliozoan peaks occurred only when crustacean numbers were low, and that major peaks of heliozoans and rotifers alternated in summer.

We also applied multivariate statistics on the combined data sets from 0 to 8 and 8 to $20 \mathrm{~m}$ to test for potential synergistic effects of several variables (temperature, chlorophyll $a_{1}$ ciliates, rotifers, bacteria and autotrophic picoplankton). Multiple linear regression with the raw and log-transformed data set revealed that chlorophyll a was indeed the only parameter that significantly $(\mathrm{p}<0.001)$ impacted heliozoan cell numbers during the period when heliozoans were present. Overall, chlorophyll a accounted for $36 \%$ of the variance of total heliozoan abundance (adjusted $r^{2}=0.361$, $\mathrm{n}=35$ ),

The seasonal succession of heliozoan genera was similar at both sampling stations (Fig. 4). The only clear difference was the spring peak of Actinophrys at the littoral station with 4 times higher cell numbers than at the mid-lake station. Abundance of Raphidocystis, Heterophrys and Chlamydaster was much lower in 8 to $20 \mathrm{~m}$ water depth than in the upper epilimnion in the central part of the lake. The heliozoans that were recorded first in spring were Actinophrys. Four genera tion (M2), respectively. A second peak occurred at the beginning of August, which was most expressed in 0 to $8 \mathrm{~m}$ depth (6.6 heliozoans $\mathrm{ml}^{-1}$ ) at Stn M1. Two smaller maxima were recorded in September and October. Maximum abundance in 8 to $20 \mathrm{~m}$ water depth reached only one third of the upper water column $(2.0$ heliozoans $\mathrm{ml}^{-1}$ ). Averaged over the investigation period, cell numbers in this stratum reached $75 \%$ of the 0 to $8 \mathrm{~m}$ depth layer.

We compared the seasonal course of heliozoan numbers at the mid-lake station to chlorophyll a concentration, which we took as an indicator of the availability of autotrophic prey, and to numbers of major zooplankton taxa,

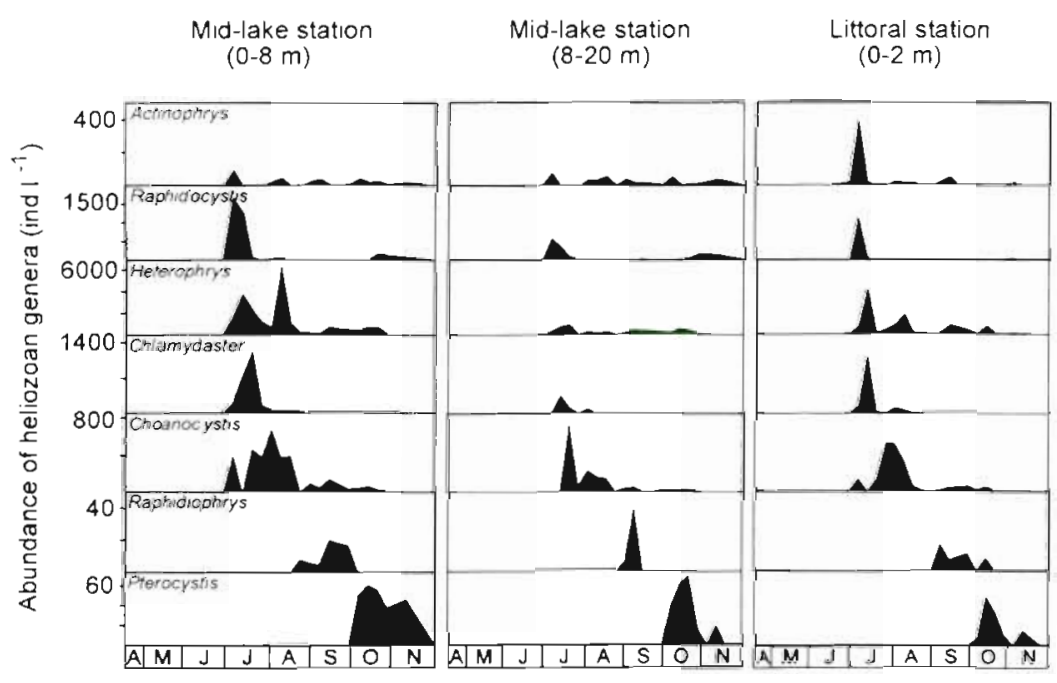

Fig. 4. Seasonal course of abundance of dominant heliozoan genera at the 2 routine sampling stations 
occurred from June to November, whereas the following 3 genera were restricted to shorter periods: Chlamydaster (July/August), Raphidiophrys (August/September at the mid-lake and September/October at the littoral station, respectively), and Pterocystis (October/November). Choanocystis, Raphidiophrys and Pterocystis reached the same or even higher maximum abundance in 8 to $20 \mathrm{~m}$ water depth than in 0 to $8 \mathrm{~m}$ depth.

From July to mid-October, the heliozoan community was dominated by small genera with cell diameters between 10 and $20 \mu \mathrm{m}$. Mainly Heterophrys, Chlamydaster and Choanocystis contributed to total heliozoan abundance. In early summer and late autumn, however, the larger heliozoans like Actinophrys and Raphidocystis reached 57 to $100 \%$ of total heliozoan abundance.

The seasonal course of total heliozoan biovolume was also similar at both stations (Fig. 5). Maximum biovolumes were recorded in July with $59.0 \mathrm{~mm}^{3} \mathrm{~m}^{-3}$ at the mid-lake station in 0 to $8 \mathrm{~m}$ depth and $59.8 \mathrm{~mm}^{3} \mathrm{~m}^{-3}$ at the littoral station. Peaks in August, September and October were less distinct than corresponding abundance maxima. In deeper water ( 8 to $20 \mathrm{~m}$ ) the highest biovolume reached only one-third $\left(20.5 \mathrm{~mm}^{3} \mathrm{~m}^{-3}\right)$ of the value recorded in the near-surface layer $(0$ to $8 \mathrm{~m})$.

Three heliozoan genera were the major contributors to biovolume: Actinophrys, Raphidocystis and Heterophrys (Fig. 6). Actinophrys and Raphidocystis, due to their large cell volume, reached high percentages of total biovolume even when their cell numbers were low. The maximum biovolume recorded at the beginning of July was 90 to $95 \%$ composed of these 2 genera. The small genus Heterophrys contributed substantially to total heliozoan biovolume because of its high cell numbers in mid-summer. Biovolumes of
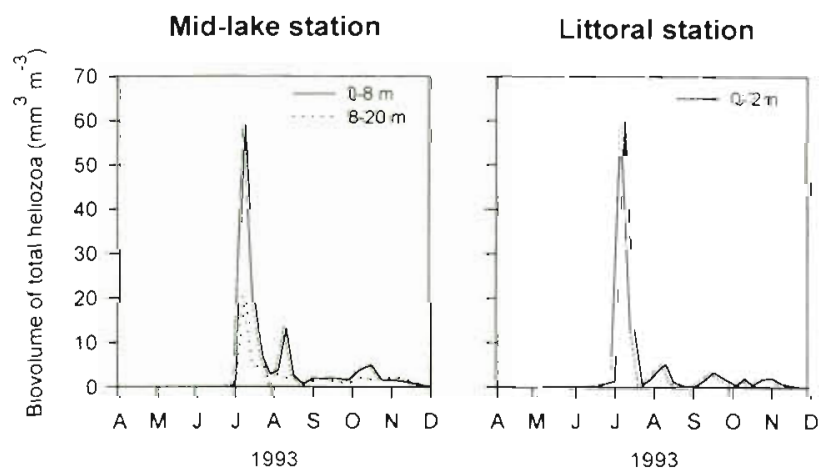

Fig. 5. Seasonal course of heliozoan biovolume. Left: mid-lake station (M1) 0 to $8 \mathrm{~m}$ (solid line) and 8 to $20 \mathrm{~m}$ (dotted line). Right: littoral station 0 to $2 \mathrm{~m}$
Raphidiophrys and Pterocystis were 1 to 2 orders of magnitude lower than those of the other genera.

\section{Vertical and horizontal distribution}

The vertical distribution of heliozoans was examined at the mid-lake station in Überlinger See on 2 occasions in summer and autumn. In both cases, the community was numerically dominated by small heliozoans $(<20 \mu \mathrm{m})$. Only a few heliozoans $>30 \mu \mathrm{m}$ in cell diameter were recorded. Both depth profiles are shown in relation to chlorophyll $a$ and temperature (Fig 7). In summer, heliozoan abundance peaked at $6 \mathrm{~m}$ water depth. Below $6 \mathrm{~m}$ there was a steady strong decline in cell number except for a second, less developed maximum at $15 \mathrm{~m}$ depth. We observed only a few heliozoans deeper than $20 \mathrm{~m}$. Total cell numbers were lower in autumn than in summer. Highest heliozoan cell numbers were recorded at $10 \mathrm{~m}$ water depth. A smaller peak occurred in $4 \mathrm{~m}$ depth. Below the thermocline abundance declined rapidly, and at $50 \mathrm{~m}$ only 8 heliozoans $1^{-1}$ were recorded. Both depth profiles were significantly positively correlated with chlorophyll a (summer: $\mathrm{p}<0.01, \mathrm{r}^{2}=0.61, \mathrm{n}=11$; autumn: $\mathrm{p}<$ $0.01, r^{2}=0.69, n=11$ ). A multiple linear regression with both vertical profiles combined revealed that temperature as well as chlorophyll a was highly significantly ( $p<0.001$ ) related to the vertical distribution of heliozoan abundance. The combined effect of both variables explained $80 \%$ of the total variance in heliozoan numbers (adjusted $\mathrm{r}^{2}=0.802$, $\mathrm{n}=22$ ).

The horizontal distribution of heliozoans in Überlinger See in the upper $8 \mathrm{~m}$ of the water column was investigated in early August (Fig. 8). Variation of abi- 

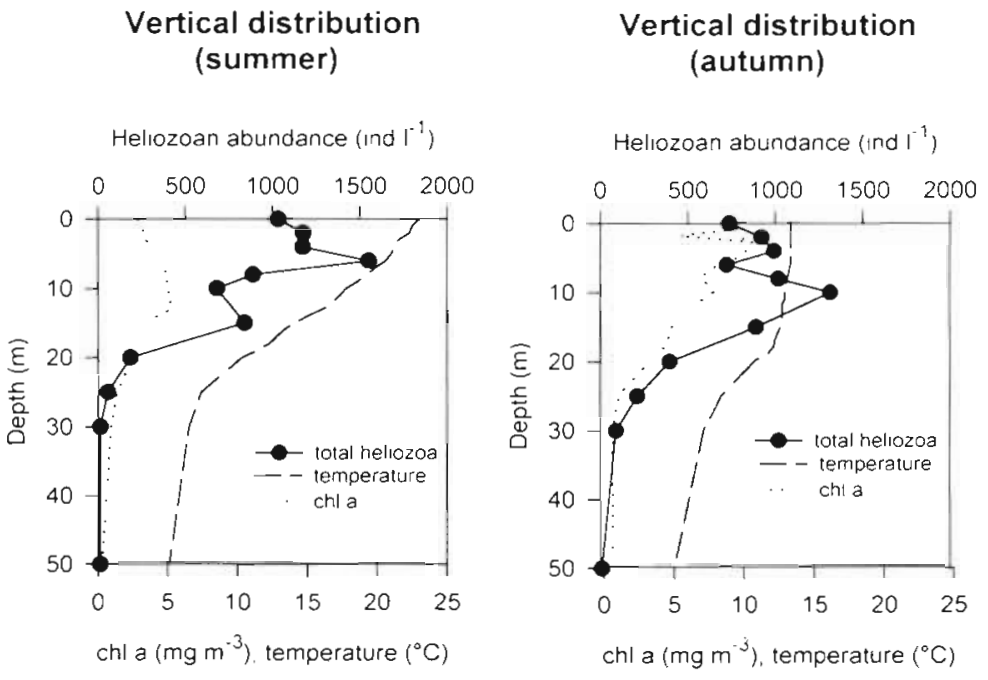

Fig. 7 Vertical distribution of total heliozoan abundance (solid line) in relation to temperature (dashed line) and chlorophyll a (dotted line) at the mid-lake station in summer (left) and autumn (right)

\section{Horizontal distribution}

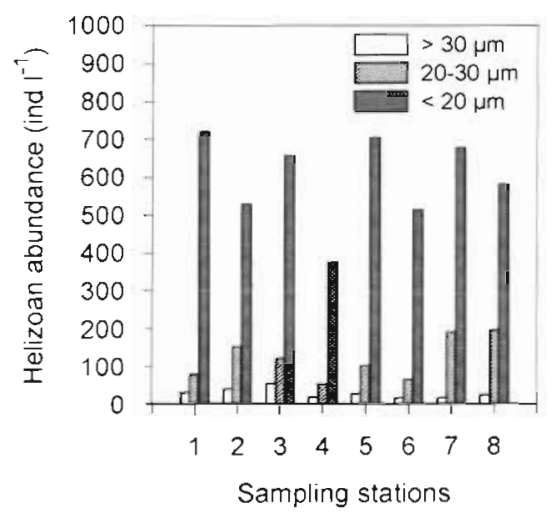

Fig. 8. Horizontal distribution of heliozoan abundance in 3 size classes across the northwestern part of Lake Constance on August 3, 1993 (0 to $8 \mathrm{~m}$ )
Small specimens $(<20 \mu m)$ dominated the heliozoan community at all stations. The size class $20-30 \mu \mathrm{m}$ reached 10 to $25 \%$ of total heliozoan cell numbers, and large heliozoans $(>30 \mu \mathrm{m})$ contributed only 2 to $7 \%$ to maximum abundance.

\section{In situ growth rates}

In situ growth experiments were carried out in summer and autumn close to the routine littoral station (Fig. 1). Water temperature at the sampling depth $(3 \mathrm{~m})$ was $20^{\circ} \mathrm{C}$ throughout the whole summer experiment. The community growth rate calculated from cellular changes in both diffusion chambers was $0.32 \mathrm{~d}^{-1}$, equivalent to a generation time of 2.2 d (Table 2). Growth rates of single genera varied between 0.06 and $0.39 \mathrm{~d}^{-1}$, generation times ranged from 2.2 to $11.6 \mathrm{~d}$. Highest growth rates $\left(0.39 \mathrm{~d}^{-1}\right)$ were measured for the genus Chlamydaster Surprisingly, growth rates were generally higher in autumn when water temperature was only $14^{\circ} \mathrm{C}$. At this time Choanocystis and Rhaphidiophrys reached the highest growth rates corresponding to generation times of only $1.2 \mathrm{~d}$ (Table 2 ).

\section{DISCUSSION}

Ours is the first study that investigated the seasonal dynamics and ecological role of planktonic heliozoans in a large, mesotrophic lake. We examined, however, only planktonic heliozoans. Species that colonize macrophytes or the sediment surface were not recorded in this study. Lake snow particles which are known to be populated by heliozoans (Laybourn-Parry otic and biotic parameters was relatively small at the different stations. Secchi-depth readings ranged from 2.5 to $3.1 \mathrm{~m}$, temperature from 17.6 to $19.7^{\circ} \mathrm{C}, \mathrm{pH}$ from 8.5 to 8.7 , and chlorophyll a concentrations from 11.7 to $12.5 \mathrm{mg} \mathrm{m}^{-3}$. Cell numbers of heliozoa varied by a factor of 2 across the lake. Differences between central and near shore stations were insignificant. Heliozoan abundance was not significantly correlated to any of the following abiotic or biotic factors: temperature, $\mathrm{pH}$, chlorophyll a, concentrations of macronutrients, bacteria, heterotrophic flagellates, and ciliates.
Table 2. Growth rates and generation times of heliozoans in summer (mid-August) and autumn (end of September). Mean values from 2 diffusion chambers each

\begin{tabular}{|c|c|c|c|c|}
\hline & \multicolumn{2}{|c|}{ Summer } & \multicolumn{2}{|c|}{ Autumn } \\
\hline & $\begin{array}{l}\text { Growth } \\
\text { rate } \mu\left(\mathrm{d}^{-1}\right)\end{array}$ & $\begin{array}{l}\text { Generation } \\
\text { time } G(d)\end{array}$ & $\begin{array}{c}\text { Growth } \\
\text { rate } \mu\left(\mathrm{d}^{-1}\right)\end{array}$ & $\begin{array}{l}\text { Generation } \\
\text { time } G(\mathrm{~d})\end{array}$ \\
\hline Community & 0.32 & 2.2 & 0.41 & 1.7 \\
\hline Actinophrys & 0.24 & 2.9 & 0.31 & 2.2 \\
\hline Chlamydaster & 0.39 & 1.8 & - & - \\
\hline Choanocystis & 0.38 & 1.8 & 0.59 & 1.2 \\
\hline Heterophrys & 0.31 & 2.2 & 0.33 & 2.1 \\
\hline Pterocystis & - & - & 0.53 & 1.3 \\
\hline Raphidiophrys & - & - & 0.58 & 1.2 \\
\hline Raphidocystis & 0.06 & 11.6 & - & - \\
\hline
\end{tabular}


et al. 1991) and the neuston, which is also a potentially important habitat for heliozoans (Petersen \& Hansen 1960), were also neglected in our investigation.

Community composition was the same at both sampling sites. We cannot exclude the possibility, of course, that populations of additional genera do exist in other parts of Lake Constance. Actinophrys, Raphidocystis and Raphidiophrys were observed as long ago as the early 1930 s in Lake Constance $(H . J$ Elster pers. comm.), while we detected the other 4 heliozoan genera for the first time. The taxonomic composition of heliozoans in Lake Constance thus seems to be very similar to that of Lake Geneva (Switzerland) where Penard (1904) found the same 7 genera at the beginning of this century. Similar to Arndt's (1993) investigation in Lake Müggelsee (Germany), the heliozoan community in Lake Constance was dominated by small, centrohelid heliozoans with cell bodies less than $20 \mu \mathrm{m}$ in diameter. Large heliozoans (Actinophrys, Raphidocystis) contributed, however, substantially to total biovolume in early summer and late autumn.

Maximum heliozoan abundance in Lake Constance was about 6500 ind. $\mathrm{l}^{-1}$. Higher cell numbers (up to 51000 ind. $1^{-1}$ ) were observed only in the highly eutrophic Lake Müggelsee (Arndt 1993) and in the mesoeutrophic lakes Neumühler See and Schalsee (Germany) (up to 77000 ind. $1^{-1}$; Mathes \& Arndt 1994). The few other heliozoan concentrations reported in the literature are lower than those found in our study: 1200 ind. $\mathrm{I}^{-1}$ in the eutrophic Lake Esthwaite (UK) (Laybourn-Parry et al. 1990), 550 ind. $\mathrm{l}^{-1}$ in mesotrophic Lake Windermere (UK) (Laybourn-Parry \& Rogerson 1993), and only 20 to 50 ind $1^{-1}$ of the genus Actinosphaerium in ultraoligotrophic Crooked Lake (Antarctica) (Laybourn-Parry et al. 1991). In the Pacific Ocean, Takahashi \& Yi Ling (1980) counted 25 heliozoans $\mathbf{l}^{-1}$ of the genus Sticholonche. These data suggest that planktonic heliozoans, like other protozoa such as ciliates (Beaver \& Crisman 1982) and heterotrophic nanoflagellates (Berninger et al. 1991, but consult Gasol \& Vaqué 1993), are positively related to lake trophy.

In Lake Constance cell numbers varied considerably throughout the year with maxima occurring in summer and, less pronounced, in autumn. The seasonal development therefore confirms earlier investigations in different environments. Penard (1904) and Rainer (1968) each reported a major heliozoan peak in autumn and a smaller one in spring. A very similar seasonal development is also known from Lake Esthwaite (LaybournParry et al. 1990). Some other authors recorded highest cell numbers of planktonic sarcodines (heliozod, testaceans and naked amoebae) in summer (Arndt 1993, Mathes \& Arndt 1994).
The relationships we found to chlorophyll a, rotifers and crustaceans suggest that the abundance of heliozoans in Lake Constance is, apart from temperature, primarily driven by supply of algal food and predation by or competition with metazoan plankton. We assume that small algae were an important food source, since heliozoan abundance was significantly positively related to chlorophyll a concentration both seasonally and vertically. Furthermore, Actinophrys could be cultivated in our laboratory with a green cryptomonad as food (H. Müller unpubl.). Heterotrophic nanoflagellates (HNF), which were frequently seen attached to axopods of heliozod, might serve as additional food. In Lake Constance, however, biomass of HNF generally is insignificant relative to biomass of small algae (Müller et al. 1991).

The observed inverse trends between heliozoa and rotifers and between heliozoa and crustacea could have been caused by various mechanisms: predation, competition for common algal food (exploitative competition), and/or other interactions such as interference competition. At present, it appears premature to speculate about the exact nature of these interactions, especially since such relationships will emerge at the genus or species level rather than at the community level. The most remarkable trend was the seasonal displacement between heliozoan and rotifer peaks in summer. Predation and exploitative competition between these 2 zooplankton taxa need to be studied experimentally.

The vertical distribution confirmed the positive relationship to chlorophyll a noted above for the seasonal course. In both depth profiles investigated, heliozoan cell numbers declined rapidly below the epilimnion. This trend was also apparent at the mid-lake station where cell numbers in 8 to $20 \mathrm{~m}$ were lower than in 0 to $8 \mathrm{~m}$ throughout the year. In marine environments highest abundances of sarcodines (Caron \& Swanberg 1990 and references therein) and of the heliozoan species Sticholonche zanclea (Takahashi \& Yi Ling 1986) have also been reported from the euphotic zone. The food spectrum of planktonic heliozoans has received only little attention. Our findings support the assumption that most heliozoans prefer algal food (Page \& Siemensma 1991). The extent to which smaller species may feed upon other protozoa and bacteria awaits experimental study. Large species such as Actinophrys seem to be carnivorous or omnivorous (Page \& Siemensma 1991, Arndt 1993).

In contrast to the long prevailing opinion that envisaged heliozoans primarily as benthic animals living on sediment surfaces and macrophytes (Grospietsch 1958, Rainer 1968, Bérzinš \& Stensdotter 1990, Caron \& Swanberg 1990) we found only minor differences between the pelagic and the littoral sampling site. 
Only Actinophrys reached 4 times higher maximal cell numbers inshore than in the central lake. In contrast to other heliozoan species, Actinophrys seems to prefer macrophytes like Chara sp. and Potamogeton sp. as habitat (Bérzinš \& Stensdotter 1990). These macrophytes were dominant at our littoral sampling station.

Our case study on the horizontal variation across Lake Constance did not confirm the very patchy distribution of heliozoans noted by Rainer (1968). The horizontal range of heliozoan cell numbers by a factor of 2 is similar to horizontal changes found for the immobile autotrophic picoplankton in Lake Constance (Weisse \& Kenter 1991).

Until now, there have been few reports concerning growth and production of heliozoans. Tobiesen (1991) described growth rates between 0.23 and $1.59 \mathrm{~d}^{-1}$ for Heterophrys marina. In his laboratory experiments growth was impacted by prey species, prey concentration and temperature. In enclosure experiments $U$ Stensdotter (pers. comm.) found an increase of heliozoan abundance and biomass with increasing $N$ and $P$ concentration, and with decreasing cell numbers of large zooplankton. In situ growth rates obtained in our study ranged from 0.06 to $0.59 \mathrm{~d}^{-1}$ for heliozoan genera. Higher growth rates in autumn in spite of lower water temperature might have been caused by better food quality due to enhanced nutrient supply. We cannot rule out the possibility that our growth rate calculations are underestimates because some heliozoans were sensitive to the experimental treatment and enclosure in the diffusion cages. Yet we never observed that heliozoans were damaged at the end of the incubation period and we therefore assume that our results give valid estimates of heliozoan in situ growth rates.

Using our biovolume data and results from the growth experiments, we may provide a tentative estimate of heliozoan productivity in Lake Constance for the upper $20 \mathrm{~m}$ of the water column. Due to the lack of a heliozoan-specific carbon to volume conversion factor we assumed the conversion factor of $110 \mathrm{fg} \mathrm{C}$ $\mu \mathrm{m}^{-3}$ given for ciliates (Turley et al. 1986). Heliozoan biomass thus calculated varied between 0 and $4 \mathrm{mg} \mathrm{C}$ $\mathrm{m}^{-3}$ from April through November with a mean value of $0.3 \mathrm{mg} \mathrm{C} \mathrm{m} \mathrm{m}^{-3}$. To calculate production, we used the mean gross growth rate $\left(\mu=0.37 \mathrm{~d}^{-1}\right)$ obtained from our in situ growth experiments. Mean heliozoan production in Lake Constance would thus have ranged from 0 to $1.5 \mathrm{mg} \mathrm{C} \mathrm{m} \mathrm{Cm}^{-1}$ throughout the study period. The seasonal mean heliozoan production estimate of $0.1 \mathrm{mg} \mathrm{C} \mathrm{m} \mathrm{C}^{-1}$ is low relative to other planktonic protozoans in Lake Constance. Ciliate production derived from similar in situ growth experiments conducted at the mid-lake station ranged from 0.7 to $13.3 \mathrm{mg} \mathrm{C} \mathrm{m} \mathrm{m}^{-3} \mathrm{~d}^{-1}$, heterotrophic nanoflagellate production from 0 to $9.4 \mathrm{mg} \mathrm{C} \mathrm{m} \mathrm{m}^{-3} \mathrm{~d}^{-1}$ (Weisse unpubl.). The average annual production calculated for these protozoans in Lake Constance is $4.9 \mathrm{mg} \mathrm{C} \mathrm{m}^{-3}$

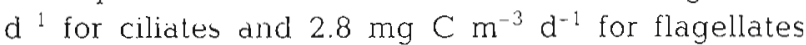
(Weisse unpubl.). Similar flagellate and ciliate production estimates in Überlinger See have been calculated by Gaedke \& Straile (1994), based on biomass data and theoretical assumptions. Their values for the upper $20 \mathrm{~m}$ of the water column in different seasons range from 38 to $55 \mathrm{mg} \mathrm{C} \mathrm{m} \mathrm{C} \mathrm{d}^{-1}$ (1.9 to $2.7 \mathrm{mg} \mathrm{C} \mathrm{m} \mathrm{m}^{-3}$ $\mathrm{d}^{-1}$ ) for heterotrophic nanoflagellates and from 45 to $153 \mathrm{mg} \mathrm{C} \mathrm{m} \mathrm{m}^{-2} \mathrm{~d}^{-1}$ (2.2 to $7.6 \mathrm{mg} \mathrm{C} \mathrm{m} \mathrm{m}^{-3} \mathrm{~d}^{-1}$ ) for ciliates. We therefore conclude that, on an annual average, heliozoa contribute only about $1 \%$ to total protozoan productivity while at their seasonal peak they reach production values comparable to those of flagellates and ciliates.

Sarcodine production data from other lakes are still lacking. According to Arndt (1993), sarcodine biomass in eutrophic Lake Müggelsee contributed 1 to $15 \%$ to the annual mean protozooplankton biomass. In a similar study in 19 north German lakes, Mathes \& Arndt (1994) calculated an average contribution of sarcodines to protozoan biomass of $2.4 \%$. This suggests that the contribution of heliozoa to total protozoan production might also be small in these lakes, which is in agreement with our results from Lake Constance.

In conclusion, our investigation demonstrated that heliozoans on average contribute only little to the overall planktonic productivity in a moderately large, mesotrophic lake. At their seasonal peak, however, they reach biomasses comparable to those of smaller protozoa, i.e. ciliates and heterotrophic flagellates. Apparently, mainly small heliozoans $(<20 \mu \mathrm{m})$ are much more prominent in the plankton than hitherto assumed. Heliozoan genera show a distinct seasonal succession comparable to the succession observed in ciliate species (e.g. Müller et al. 1991). With the present study we have only begun to understand the factors that potentially impact the seasonal and spatial distribution of heliozoans. Clearly, more qualitative and quantitative investigations in a variety of lakes of different trophy are necessary to achieve a better insight into the ecology of planktonic heliozoa.

Acknowledgements. We thank B. Beese, G. Richter, G. Schulze, and $S$. Wölfl who provided unpublished data on chlorophyll $a$, ciliates, rotifers and crustacea in Lake Constance. The continuous cooperation of Captain K. Wiedemann aboard RV 'Robert Lauterborn' is gratefully acknowledged. Klaus Jürgens, Ulrich Kenter, and Sue Mitchell commented on an earlier version of the manuscript. We also thank 2 anonymous referees for their constructive criticism. This study was supported by Deutsche Forschungsgemeinschaft within the Special Collaborative Program 'Cycling of Matter in Lake Constance' (SFB 248). 


\section{LITERATURE CITED}

Arndt $H$ (1993) A critical review of the importance of rhlzopods (naked and testate amoebae) and actinopods (heliozoa) in lake plankton. Mar Microb Food Webs 7: $3-29$

Beaver JR, Crisman TL (1982) The trophic response of ciliated protozoans in freshwater lakes. Limnol Oceanogr 27 : $246-253$

Berninger UG, Finlay BJ, Kuuppo-Leinikki P (1991) Protozoan control of bacterial abundances in freshwater. Limnol Oceanogr 36:139-147

Bérzins B, Stensdotter U (1990) Ecological studies of freshwater rhizopods. Hydrobiologia 202:1-11

Caron DA, Swanberg NR (1990) The ecology of planktonic sarcodines. Rev Aquat Sci 3:147-180

Gaedke U, Straile D (1994) Seasonal changes of the quantitative importance of protozoans in a large lake. An ecosystem approach using mass-balanced carbon flow diagrams. Mar Microb Food Webs 8:163-188

Gasol JM, Vaqué D (1993) Lack of coupling between heterotrophic nanoflagellates and bacteria: a general phenomenon across aquatic systems? Limnol Oceanogr 38 : $657-665$

Geller W, Güde H (1989) Lake Constance-the largest German lake. In: Lampert W, Rothhaupt $\mathrm{KO}$ (eds) Limnology in the Federal Republic of Germany. Carius, Kiel, p $9-17$

Grospietsch T (1958) Wechseltierchen (Rhizopoden). Franck'sche Verlagshandlung, Stuttgart

Güde H (1986) Loss processes influencing growth of planktonic bacterial populations in Lake Constance. J Plankton Res 8:795-810

Jürgens K, Güde H (1991) Seasonal changes in the grazing impact of phagotrophic flagellates on bacteria in Lake Constance. Mar Microb Food Webs 5:27-37

Lampert W (1978) Climatic conditions and planktonic interactions as factors controlling the regular succession of spring algal blooms and extremely clear water in Lake Constance. Int Verh Verein Limnol 20:969-974

Laybourn-Parry J, Marchant HJ, Brown P (1991) The plankton of a large oligotrophic freshwater Antarctic lake. J Plankton Res 13:1137-1149

Laybourn-Parry J, Olver J, Rogerson A, Duvergé PL (1990) The temporal and spatial patterns of protozooplankton abundance in a eutrophic temperate lake. Hydrobiologia 203:99-110

Laybourn-Parry J, Rogerson A (1993) Seasonal patterns of protozooplankton in Lake Windermere, England. Arch Hydrobiol 129:25-43

Lozán JL (1992) Angewandte Statistik für Naturwissenschaftler. Pareys Studientexte Nr 74. Parey, Berlin

Responsible Subject Editor: K. Simek, České Budējovice, Czech Republic
Mathes J, Arndt H (1994) Biomass and composition of protozooplankton in relation to lake trophy in north German lakes. Mar Microb Food Webs 8:357-375

Müller $H$ (1989) The relative importance of different ciliate taxa in the pelagic food web of Lake Constance. Microb Ecol 18:261-273

Müller H, Schöne A, Pinto-Coelho RM, Schweizer A, Weisse $T$ (1991) Seasonal succession of ciliates in Lake Constance. Microb Ecol 21:119-138

Müller H, Weisse T (1994) Laboratory and field observations on the scuticociliate Histiobalantium from the pelagic zone of Lake Constance, FRG. J Plankton Res 16:391-401

Page FC, Siemensma FJ (1991) Nackte Rhizopoda und Heliozoa. Gustav Fischer Verlag. Stuttgart

Penard E (1904) Les héliozoaires d'eau douce. Kündig, Geneva

Petersen JB, Hansen JB (1960) Elektronenmikroskopische Untersuchungen von zwei Arten der Heliozoen-Gattung Acanthocystis. Arch Protistenkd 106:547-553

Rainer H (1968) Urtiere, Protozoa; Wurzelfüßler, Rhizopoda; Sonnentierchen, Heliozoa. In: Dahl F (ed) Die Tierwelt Deutschlands, Vol 56. Gustav-Fischer-Verlag, Jena

Sommer U, Gaedke U, Schweizer A (1993) The first decade of oligotrophication of Lake Constance. II. The response of phytoplankton taxonomic composition. Oecologia 93: $276-284$

Takahashi K, Yi Ling HY (1980) Distribution of Sticholonche (Radiolaria) in the upper $800 \mathrm{~m}$ of the waters in the equatorial Pacific. Mar Micropaleontol 5:311-319

Tilzer MM, Gaedke U, Schweizer A, Beese B, Wieser T (1991) Interannual variability of phytoplankton productivity and related parameters in Lake Constance: no response to decreased phosphorus loading? J Plankton Res 13: $755-777$

Tobiesen A (1991) Growth rates of Heterophrys marina (Heliozoa) on Chrysochromulina polylepis (Prymnesiophyceae). Ophelia 33:205-212

Turley CM, Newell RC, Robins DB (1986) Survival strategies of two small marine ciliates and their role in regulating bacterial community structure under experimental conditions. Mar Ecol Prog Ser 33:59-70

Utermöhl H (1958) Zur Vervollkommnung der quantitatıven Phytoplankton-Methodik. Mitt lnt Verein Theor Angew Limnol 9:1-38

Weisse T (1990) Trophic interactions among heterotrophic microplankton, nanoplankton and bacteria in Lake Constance. Hydrobiologia 191:111-122

Weisse I (1991) The annual cycle of heterotrophic freshwater nanoflagellates: role of bottom-up versus top-down control. J Plankton Res 13:167-185

Weisse T, Kenter U (1991) Ecological characteristics of autotrophic picoplankton in a prealpine lake. Int Rev Ges Hydrobiol 76:493-504

Manuscript first received: December 2, 1995 Revised version accepted: May 2, 1996 